\title{
STRATEGI PELAKSANAAN KEGIATAN KEAGAMAAN DI TENGAH PANDEMI COVID-19 PADA MASYARAKAT KELURAHAN WONOKARTO KABUPATEN WONOGIRI
}

\author{
Muhammad Yusril Marom ${ }^{1}$, Agus Machfud Fauzi ${ }^{2}$ \\ Universitas Negeri Surabaya, Jawa Timur, Indonesia \\ E-mail:m.yusrilmarom@gmail.com¹, agusmfauzi@unesa.ac.id ${ }^{2}$
}

\begin{abstract}
Abstrak
Pandemi covid-19 telah banyak mempengaruhi struktur sosial masyarakat. Termasuk dalam aktivitas keagamaan, masyarakat di Kelurahan Wonokarto Kabupaten Wonogiri dalam beribadah serba dibatasi, sehingga menyulitkan masyarakat setempat untuk menenunaikan tradisi kegamaan secara khidmat. Beberapa bentuk pembatasannya dalam hal ini seperti pembatasan dari segi jumlah jama'ah, pembatasan dalam melakukan kontak sosial, sampai berupa larangan untuk melaksanakan sholat di masjid. Adanya pembatasan ini diklaim merupakan bentuk kebijakan pemerintah dalam rangka meminimalisir penyebaran virus covid-19. Hal ini karena kegiatan keagamaan yang dilakukan oleh masyarakat beresiko menimbulkan kerumunan yang dapat menyebabkan penularan virus semakin luas. Penelitian ini akan lebih menyoroti pada bagaimana upaya-upaya atau strategi yang dilakukan masyarakat Kelurahan Wonokarto untuk bisa tetap mengadakan kegiatan keagamaan di masa pandemi Covid-19. Tujuan dari penelitian ini adalah untuk mengetahui upaya maupun stretegi yang dilakukan masyarakat dalam menemukan solusi aman penyelenggaraan kegiatan keagamaan di masa pandemi. Metode yang digunakan adalah kualitatif yang bersifat deskriptif. Hasil temuan menunjukkan bahwa di tengah masa pandemi masih banyak kegiatan keagamaan yang dilakukan masyarakat Kelurahan Wonokarto, diantaranya seperti tadarus, tahlilan, pengajian, dan kegiatan lainnya. Melalui perspektif teori rasionalitas milik Max Weber, ditemukan bahwa masyarakat setempat memiliki beberapa strategi dalam melaksanakan kegiatan keagamaan supaya dapat berjalan dengan aman. Strategi tersebut mencakup prinsip rasionalitas yang diungkapkan Weber, yaitu tindakan rasional berorientasi nilai, rasionalitas instrumental, tindakan tradisional, dan tindakan afektif.

Kata kunci: kegiatan keagamaan, pandemi covid-19, strategi
\end{abstract}

\section{PENDAHULUAN}

Virus Covid-19 (Coronavirus disease 2019) atau yang lebih dikenal dengan virus corona merupakan corona virus jenis baru (SARS-CoV-2). Virus ini paling sering dijumpai menyerang sistem pernapasan dan dapat menyebabkan infeksi paru-paru yang parah, sampai menimbulkan kematian. ${ }^{1}$ Virus corona secara resmi diumumkan pemerintah singgah ke Indonesia pada awal tahun 2020, tepatnya tanggal 2 Maret $2020 .^{2}$ Sebelum masuk ke Indonesia, virus ini juga telah menyebar

\footnotetext{
${ }^{1}$ Fadli Rizal, “Coronavirus,” Halodoc.com, 2021, https://www.halodoc.com/kesehatan/coronavirus.

2 Yandri Daniel Damaledo, "2 Maret 2020 Kasus Corona Pertama Di Indonesia Diumumkan Tahun Lalu," Tirto.id, 2021, https://tirto.id/2-maret-2020-kasus-corona-pertama-di-indonesia-diumumkan-tahun-lalugaKw.
}

Al Qalam: Jurnal Ilmiah Keagamaan dan Kemasyarakatan Vol. 15, No. 2 Juli-Desember 2021 
luas terlebih dahulu di Kota Wuhan, Tiongkok pada akhir Bulan Desember 2019. Dampaknya tidak hanya di Indonesia, bahkan di hampir seluruh negara di dunia diguncang dengan keberadaan

makhluk kecil ini. ${ }^{3}$ Akibat yang ditimbulkan dari wabah virus corona adalah keresahan bagi masyarakat dan berdampak di hampir segala lini kehidupan mulai dari segi ekonomi, sosial, pendidikan budaya, dan masih banyak lagi.

Salah satu dampak Covid 19 adalah berpengaruh terhadap aspek sosial keagamaan masyarakat. Indonesia sebagai negara yang memiliki prinsip ketuhanan dengan banyaknya agama di dalamnya memberikan kebebasan kepada warganya untuk memilih agama yang diinginkan. ${ }^{4}$ Berdasarkan data yang dirilis melaui situs indonesia.go.id, ada enam agama yang diakui di Indonesia, yaitu Islam sebagai agama mayoritas, Protestan, Kristen, Buddha, Katolik, dan Konghucu. ${ }^{5}$ Dengan adanya berbagai macam agama di Indonesia, tiap pemeluk agama pada masyarakat di Indonesia memiliki ciri khasnya masing-masing dalam penyelenggaraan agenda keagamaan. Namun di saat mewabahnya pandemi, kegiatan keagamaan kerap terkendala karena kebijakan pembatasan yang dikeluarkan pemerintah. Salah satu kebijakan yang dimaksud adalah Pembatasan Sosial Berskala Besar (PSBB) yang mana diluncurkan untuk meredam kerumunan di tengah masyarakat. Akibat dari penerapan PSBB dalam lingkup keagamaan adalah kegiatan keagamaan semakin dipersempit dalam penyelenggaraannya. Pada Umat Kristiani memiliki agenda keagamaan berupa perayaan Hari Paskah, namun ketika pandemi gereja menjadi sepi. Pengadaan kegiatan keagamaan beralihfungsi diadakan secara daring di rumah masing-masing. ${ }^{6}$ Pada Umat Budha, penyelenggaraan Hari Raya Waisak yang biasanya diadakan di Candi Borobudur bahkan ditiadakan. ${ }^{7}$ Kemudian bagi Umat Hindu, seperti yang terjadi di Bali mereka melakukan rutinitas Upacara Melasti untuk memeriahkan perayaan Hari Raya Nyepi namun juga dibatasi karena kebijakan pembatasan. ${ }^{8}$ Pemerintah Bali menghimbau agar upacara ini dilakukan oleh orang-orang tertentu saja, tidak seperti sebelumnya yang bisa diikuti oleh warga umum. Tidak jauh berbeda dengan agama-agama lainnya, penyelenggaraan kegiatan keagamaan serba dibatasi, menjadikan banyak momentum keagamaan di Indonesia sejak pandemi menjadi sepi, tidak semeriah di tahuntahun sebelumnya.

Tidak hanya pada momentum keagamaan di hari-hari besar, dampak pembatasan saat pandemi juga terasa pada rutinitas ibadah keseharian pada Masyarakat Kelurahan Wonokarto Kabupaten Wonogiri yang menjadi obyek kajian peneliti. Islam sebagai agama mayoritas di

\footnotetext{
${ }^{3}$ Yasinta Rahmawati, "Dari China, Begini Awal Penyebaran Virus Corona Ke Seluruh Dunia," Suara.com, 2020, https://www.suara.com/health/2020/04/04/183648/dari-china-begini-cara-penyebaran-virus-coronake-seluruh-dunia?page=all.

${ }^{4}$ Ika, "Mahfud MD Tegaskan Indonesia Bukan Negara Agama | Universitas Gadjah Mada," ugm.ac.id, 2018, https://www.ugm.ac.id/id/berita/16888-mahfud-md-tegaskan-indonesia-bukan-negara-agama.

${ }^{5}$ Siti Nur Aeni, "Mengulas Enam Agama Di Indonesia Dari Sejarah Sampai Tempat Ibadah - Nasional Katadata.Co.Id," katadata.co.id, 2021, https://katadata.co.id/sitinuraeni/berita/615bd585217fe/mengulasenam-agama-di-indonesia-dari-sejarah-sampai-tempat-ibadah.

${ }^{6}$ Abraham Utama, "Paskah 2020 Di Tengah Epidemi Virus Corona: 'Sejak Zaman Nenek Moyang, Baru Kali Ini Kami Dilarang Ke Gereja' - BBC News Indonesia," BBC News Indonesia, 2020, https://www.bbc.com/indonesia/indonesia-52229367.

7 Ronald Seger Prabowo, "Resmi! Perayaan Waisak 2021 Di Borobudur Ditiadakan - Suara Jateng," suarajawatengah.id, 2021, https://jateng.suara.com/read/2021/05/24/193149/resmi-perayaan-waisak-2021di-borobudur-ditiadakan.

${ }^{8}$ Ali Mustofa, "Di Karangasem, Upacara Melasti Dibatasi Maksimal 20 Orang," radarbali.jawapos.com, 2021, https://radarbali.jawapos.com/berita-daerah/dwipa/08/03/2021/di-karangasem-upacara-melastidibatasi-maksimal-20-orang.
}

Al Qalam: Jurnal Ilmiah Keagamaan dan Kemasyarakatan Vol. 15, No. 2 Juli-Desember 2021 
Muhammad Yusril Marom: Strategi Pelaksanaan Kegiatan Keagamaan di Tengah Pandemi Covid-19 pada Masyarakat Kelurahan Wonokarto Kabupaten Wonogiri

Kelurahan Wonokarto memiliki pemeluk agama dengan tradisi yang cukup kental dan masih terjaga. Sebelum adanya pandemi, warga setempat rutin melakukan kegiatan keagamaan, yaitu seperti tahlilan, pengajian di masjid, kultum, dan tentunya sholat berjamaah. Namun semenjak adanya pandemi, banyak halangan dan rintangan menghambat. Apalagi dari pemerintah diketahui kerap mengadakan razia apabila ditemukan kegiatan masyarakat yang berpotensi mengundang kerumunan, termasuk dalam kegiatan keagamaan yang kerap mengundang banyak massa. Hal ini karena dalam aktivitas keagamaan banyak melibatkan banyak orang berkumpul di satu tempat sehingga disinyalir dapat menimbulkan ancaman penyebaran virus corona yang semakin melebar.

Salah satu Masjid di Wonokarto yang terletak di lokasi strategis dan biasa ramai akan kegiatan kegamaan yaitu Masjid Al-Hidayah juga tak lepas dari dampak pandemi. Berdasarkan observasi yang dilakukan peneliti, Masjid Al-Hidayah menjadi titik sentral kegiatan keagamaan karena rutin dilakukan berbagai bentuk agenda keagamaan, mulai dari pengajian, Program Taman Pendidikan Qur'an (TPQ), kultum, tahlilan, bakti sosial, sampai ramai kegiatan sholat jamaah setiap lima waktu sholat. Tidak hanya Masjid Al-Hidayah, ada beberapa masjid lainnya yang juga ikut menyemarakkan kegiatan keagamaan walau tidak seramai kegiatan di Masjid Al-Hidayah.

Permasalahan yang ditimbulkan dari fenomena pandemi covid-19 adalah kini kegiatan keagamaan di masjid serba dibatasi, sampai sering ditiadakan. Pemerintah Kota Wonogiri dalam menekan laju penyebaran virus juga menerapkan kebijakan Pembatasan Sosial Berskala Besar (PSBB). Imbas dari penerapan PSBB adalah tindakan preventif seperti pembatasan fasilitas publik, pembatasan jam buka toko atau swalayan, blokade alun-alun kota dari kegiatan sosial, dan pemberian sanksi sosial bagi para pelanggar kebijakan ini. Kebijakan yang juga menjadi prioritas utama pemerintah adalah social distancing yang bertujuan untuk membatasi masifnya interaksi masyarakat agar terhindar dari kerumunan yang dapat memicu virus. ${ }^{9}$ Terkhususkan dalam aspek keagamaan, kebijakan tersebut jelas membuat masyarakat Kelurahan Wonokarto harus menetap di rumah masing-masing dan ini menyulitkan mereka untuk mengadakan kegiatan keagamaan harian. Beberapa kasus yang paling sering adalah menyulitkan untuk melakukan ibadah sholat berjamaah atau ibadah bersama-sama, menghadiri kultum harian, bahkan yang lebih parah sampai ditutupnya masjid dan peniadaan Sholat Jumat. Adapun kebijakan yang berhubungan dengan upaya pembatasan sosial ini tertera dalam Undang-undang Nomor 6 Tahun 2018 tentang Kekarantinaan Kesehatan. ${ }^{10}$

Fenomena keagamaan yang terjadi di Wonogiri sesuai dalam kajian penelitian-penelitian terdahulu yang sudah ada sebelumnya. Oleh karenanya, dalam hal ini peneliti melakukan tinjauan terhadap beberapa penelitian terdahulu untuk bisa memperkaya referensi dalam penyusunan karya pada penelitian sekarang. Penelitian terdahulu pertama adalah hasil penelitian oleh Dadang Darmawan, Deni Miharja, Roro Sri Rejeki Waluyojati, dan Erni Isnaeniah yang membahas tentang sikap keberagamaaan masyarakat muslim dalam menghadapi pandemi covid-19. Hasil temuan dari penelitian ini menunjukkan bahwa terjadi perubahan dalam kegiatan keagamaan. Perubahan ditunjukkan dengan melihat keadaan sebelum dan sesudah terjadi pandemi. Sebelum terjadi

\footnotetext{
${ }^{9}$ Albitar Septian Syarifudin, "Impelementasi Pembelajaran Daring Untuk Meningkatkan Mutu Pendidikan Sebagai Dampak Diterapkannya Social Distancing," Jurnal Pendidikan Bahasa Dan Sastra Indonesia Metalingua 5, no. 1 (2020): 31-34, https://doi.org/10.21107/metalingua.v5i1.7072.

${ }^{10}$ Presiden Republik Indonesia, "Undang Undang Nomor 6 Tahun 2018 Tentang Kekarantinaan Wilayah," Undang-Undang RI § (2018), https://jdih.bsn.go.id/produk/detail/?id=730\&jns=2.
}

Al Qalam: Jurnal Ilmiah Keagamaan dan Kemasyarakatan Vol. 15, No. 2 Juli-Desember 2021 
Muhammad Yusril Marom: Strategi Pelaksanaan Kegiatan Keagamaan di Tengah Pandemi Covid-19 pada Masyarakat Kelurahan Wonokarto Kabupaten Wonogiri

pandemi ruang publik untuk kegiatan keagamaan selalu ramai dikunjungi. Sebaliknya saat pandemi terjadi, tempat ibadah menjadi sepi pengunjung. ${ }^{11}$

Penelitian terdahulu kedua berjudul "Transformasi Dakwah di Masa Pandemi Covid-19" yang ditulis oleh Ibnu Hajar S. Tulisan dalam penelitian ini menjelaskan tentang kebutuhan dakwah umat islam yang bertransformasi di masa pandemi. Dakwah dalam penelitian ini dimaknai sebagai suatu jalan atau cara penyampaian nilai-nilai kebaikan yang mana dianggap penting oleh warga muslim. Temuan dari penelitian ini mengungkapkan bahwa kegiatan dakwah di masa pandemi telah bertransformasi ke arah digitalisasi, yaitu lebih memanfaatkan platform digital seperti media sosial secara daring. ${ }^{12}$

Penelitian terdahulu ketiga adalah karya milik Muhammad Fathur Rahman yang membahas perihal representasi masyarakat aktif di tengah era wabah virus corona. Tulisan ini mengungkapkan studi terhadap kondisi ekonomi dan sosial keagamaan di Bausasran Danurejan Yogyakarta. Hasil temuan dari tulisan ini menunjukkan bahwa dari aspek ekonomi warga Bausasran Yogyakarta di tengah keterbatasan pandemi memiliki kemampuan yang cukup baik dalam menghadapi masalah ketahanan pangan, terutama bagi kelompok rentan. Dana yang diperoleh berasal dari iuran wajib serta kegiatan berbagi sembako. Selanjutnya pada aspek sosial keagamaan, kegiatan keagamaan yang bersifat dapat mengundang kerumunan ditiadakan serta menekankan protokol kesehatan yang ketat. Apa yang dilakukan masyarakat Bausasran ini menujukkan keaktifan masyarakat berdasarkan tiga faktor, yaitu pengambilan keputusan, pengetahuan, dan kekuasaan. ${ }^{13}$

Penelitian terdahulu yang selanjutnya adalah hasil riset miliki Mukran H. Usman, Andi Wayu Irawan, dan Aswar tentang syariat islam dan kemaslahatan manusia pada lingkup kegiatan keagamaan dan pendidikan di Masa New Normal. Penelitian ini mengulas bagaiamana upaya mencapai keselarasan dalam penerapan syariat islam untuk mewujudkan kesejahteraan manusia saat pandemi berlangsung. Hasil dari penelitian mengkaji tentang larangan yang dicetuskan pemerintah seperti pembatasan ruang gerak kegiatan keagamaan maupun pendidikan yang sebelumnya dilakukan secara tatap muka. Kebijakan pembatasan pemerintah dalam kajian ini adalah hal yang bisa diterima dalam syariat islam lantaran dilakukan untuk mencapai kesejahteraan dan kemaslahatan umat manusia. ${ }^{14}$

Penelitian terdahulu yang terakhir adalah jurnal yang ditulis oleh Faiq Tobroni. Penelitian yang diangkat membahas tentang pembatasan kegiatan kegamaan dalam penanganan covid-19. Hasil dari penelitian menemukan bahwa pemerintah dalam mengendalikan covid-19 memutuskan penerapan kebijakan Pembatasan Sosial Berksala Besar (PSBB), salah satunya ditujukan untuk kegiatan keagamaan karena banyak menimbulkan kerumunan. Kebijakan ini telah ditinjau melalui landasan hukum dalam aturan perundang-undangan yang disusun secara hierarkis sehingga menghasilkan temuan bahwa kebijakan pembatasan yang dilakukan oleh pemerintah setempat telah

\footnotetext{
${ }^{11}$ Dadang Darmawan et al., "Sikap Keberagamaan Masyarakat Menghadapi Wabah COVID-19," Religious: Jurnal Studi Agama-Agama Dan Lintas Budaya 4, no. 2 (2020): 115-124, https://doi.org/10.15575/rjsalb.v4i2.8596.

12 Ibnu Hajar Sainuddin, "Transformasi Dakwah Di Masa Pandemi Covid-19," 2020, 19-21, https://doi.org/10.31219/osf.io/nakhy.

${ }^{13}$ Ratna Istriyani and Muhammad Fathur Rahman, "Representasi Masyarakat Aktif Di Masa Pandemi Covid19 (Studi Ekonomi Dan Sosial Keberagamaan Di Bausasran Danurejan Yogyakarta)," Jurnal Penelitian 14, no. 2 (2020): 185-216, https://doi.org/10.21043/jp.v14i2.8108.

${ }^{14}$ Mukran H. Usman, Aswar Aswar, and Andi Wahyu Irawan, "Syariat Islam Dan Kemaslahatan Manusia Di Era New Normal Pada Kegiataan Keagamaan Dan Pendidikan," Fenomena 12, no. 1 (2020): 89-106, https://doi.org/10.21093/fj.v12i1.2456.
}

Al Qalam: Jurnal Ilmiah Keagamaan dan Kemasyarakatan Vol. 15, No. 2 Juli-Desember 2021 
Muhammad Yusril Marom: Strategi Pelaksanaan Kegiatan Keagamaan di Tengah Pandemi Covid-19 pada Masyarakat Kelurahan Wonokarto Kabupaten Wonogiri

memenuhi persyaratan HAM secara obyektif dalam hubungannya dengan pemenuhan kebutuhan hak warga negara sebagai muslim. ${ }^{15}$

Berdasarkan lima penelitian terdahulu yang sudah ada diatas, penelitian yang sekarang dilakukan peneliti memiliki perbedaan dengan tinjauan penelitian yang sudah ada sebelumnya. Letak perbedaan tersebut ada pada penelitian yang dilakukan peneliti sekarang lebih berfokus membahas upaya untuk mengetahui dan menjelaskan bagaimana strategi masyarakat Kelurahan Wonokarto dalam melaksanakan kegiatan keagamaan di tengah keterbatasan pada masa pandemi covid-19. Selain itu, penelitian ini dilakukan dengan setting tempat berada di Kelurahan Wonokarto Kabupaten Wonogiri yang mana berbeda dengan tempat-tempat penelitian sebelumnya dan belum ada penelitian sejenis di tempat yang sama.

Adanya pandemi ini membuat masyarakat harus bisa melakukan pengkondisian sebagai upaya adaptasi dari konsekuensi perubahan sosial akibat pandemi Covid-19. Masyarakat Wonokarto dalam hal ini memiliki beragam upaya dan strategi sebagai bentuk adaptasi untuk tetap mampu mengadakan kegiatan keagamaan di tengah keterbatasan pandemi. Bentuk dari usaha masyarakat dalam paper ini akan dianalisis berdasarkan kacamata teori rasionalitas milik Max Weber. Dengan teori ini maka dapat dijabarkan motif-motif apa saja yang melatarbelakangi perilaku masyarakat sehingga itu bisa mempengaruhi keputusan individu untuk bertindak, termasuk dalam hal tindakan sosial melalukan kegiatan keagamaan. Lebih lanjut, peneliti merasa tertarik untuk meneliti fenomena keagamaan pada masyarakat Kelurahan Wonokarto karena melihat masyarakat Wonokarto mampu bertahan untuk tetap melaksanakan kegiatan keagamaan dengan segala keterbatasan saat pandemi covid-19. Harapannya dengan adanya temuan dari penelitian ini mampu memperkaya kajian keilmuan sosial, khususnya yang mengkaji fenomena keagamaan saat pandemi berlangsung agar dapat menjadi rujukan untuk terbentuknya masyarakat yang lebih baik.

\section{METODE PENELITIAN}

Penelitian ini menggunakan pendekatan kualitatif. Hal ini dilakukan karena peneliti ingin menggali informasi, mengetahui, dan menjelaskan secara mendalam fenomena strategi yang digunakan masyarakat Kelurahan Wonokarto dalam melaksanakan kegiatan keagamaan di tengah pandemi covid-19. Penelitian kualitatif yang peneliti pakai adalah lebih bersifat deskriptif, dalam artian peneliti dalam hal ini berusaha untuk menjelaskan suatu fenomena melalui deskripsi cerita yang memaparkan fakta yang ditemui saat eksplorasi kejadian di lapangan. Tujuan penggunaan metode kualitatif adalah untuk memperoleh hasil perolehan data secara mendalam dan komprehensif. ${ }^{16}$ Lebih lanjut, adanya penelitian ini berfokus pada tujuan untuk mendeskripsikan bagaimana strategi atau upaya yang dilakukan masyarakat Kelurahan Wonokarto dalam mengadakan kegiatan keagamaan di masa pandemi covid-19.

Selanjutnya, perspektif teori yang digunakan sebagai pendekatan dalam penelitian ini adalah teori rasionalitas milik Max Weber. Teori miliknya menjelaskan bahwa setiap tindakan yang dilakukan individu dalam masyarakat memiliki kecenderungan sehingga menjadi motivasi tersendiri untuk menentukan pilihan keputusan yang tepat. Menurut pandangan Max Weber, setiap perilaku individu dapat diketahui makna subjektif dibaliknya yang menjadikan dorongan untuk

\footnotetext{
15 Faiq Tobroni, "Pembatasan Kegiatan Keagamaan Dalam Penanganan Covid-19," Jurnal Komunikasi Hukum (JKH) Universitas Pendidikan Ganesha Vol. 6, no. 2 (2020): 369-395.

${ }^{16}$ Moleong Lexy J., "Metodologi Penelitian KualitatiI” (Bandung: PT. Remaja Rosadakarya, 2011), 11.
}

Al Qalam: Jurnal Ilmiah Keagamaan dan Kemasyarakatan Vol. 15, No. 2 Juli-Desember 2021 
Muhammad Yusril Marom: Strategi Pelaksanaan Kegiatan Keagamaan di Tengah Pandemi Covid-19 pada Masyarakat Kelurahan Wonokarto Kabupaten Wonogiri

melakukan sesuatu. ${ }^{17}$ Maka melalui teori ini dapat menjadi metode untuk menganalisis makna dibalik upaya-upaya yang dilakukan masyarakat dalam menghadapi sesuatu. Dalam artian lain apabila disangkutkan dengan tema penelitian kali ini, strategi yang dilakukan masyarakat Kelurahan Wonokarto memiliki makna tersendiri yang kemudian mendasari mereka untuk melakukan sesuatu berdasarkan pertimbangan yang ada. Alih-alih bertahan di rumah, masyarakat setempat lebih memilih untuk mengadakan kegiatan keagamaan walaupun di tengah situasi pandemi covid-19 yang membahayakan.

Lokasi penelitian berada di Kelurahan Wonokarto Kecamatan Wonogiri Kabupaten Wonogiri. Kemudian subjek penelitian ditentukan berdasarkan teknik purposive sampling yaitu pertimabangan yang sesuai dengan kriteria dalam penelitian ini, yang mana subjeknya akan berfokus kepada bapak-bapak atau ibu-ibu rumah tangga serta pemuda yang rutin melakukan kegiatan keagmaan seperti tahlilan dan pengajian. Subjek dipilih karena berkaitan sebagai pihak yang merasakan langsung kegiatan keagamaan sehingga bisa diketahui bagaimana alasan dibalik strategi upaya yang mereka gunakan.

Teknik pengumpulan data dalam penelitian ini menggunakan sumber data primer dan data sekunder. Data primer didapatkan peneliti saat melakukan pengamatan dan wawancara langsung dengan narasumber. Perolehan data disini lebih banyak didapatkan melalui komunikasi virtual melalui aplikasi WhatsApp karena alasan pembatasan sosial saat pandemi sehingga sulit untuk tatap muka secara langsung. Peneliti juga banyak memanfaatkan data sekunder melalui pengambilan informasi yang ada di jurnal, berita, penelitian terdahulu, dan sumber pendukung lainnya untuk memperkuat posisi penelitian.

Setelah data terkumpul, dilakukan teknik analisis data yang bertujuan supaya data-data yang sudah didapatkan sebelumnya dapat disusun sesuai kaidah agar bisa lebih mudah dipahami dan ditarik sebuah kesimpulan sebagai hasil dari penelitian. Teknik analisis data yang dilakukan peneliti terdiri dari tiga tahapan. Dimulai dari mereduksi data, data-data yang telah diperoleh sebelumnya disaring, dikelompokkan, ditentukan mana yang bisa dipakai mana yang tidak bisa, untuk mempermudah dalam klarifikasi klasifikasi data. Setelah mengalami proses seleksi, langkah selanjutnya adalah penyajian data, dalam hal ini peneliti menyajikan data dari hasil data yang sudah direduksi. Kemudian tahapan yang terakhir adalah penarikan kesimpulan, yaitu menarik garis pokok dari hasil temuan data yang mewakili bagaimana gambaran fenomena dari strategi masyarakat Wonokarto dalam menunaikan aktivitas keagamaan di tengah situasi pandemi covid19.

\section{HASIL DAN PEMBAHASAN}

\subsection{Kondisi Obyektif Kegiatan Keagamaan pada Masyarakat Wonokarto}

Kelurahan Wonokarto adalah salah satu kelurahan yang terletak di jantung Kota Wonogiri. ${ }^{18}$ Masyarakat di kelurahan ini adalah masyarakat yang lekat dengan gaya hidup kota karena secara geografis terletak tidak jauh dari pusat perkotaan. Berdasarkan pengamatan dan observasi peneliti, sebagian besar masyarakat Wonokarto memiliki ciri karakter yang religius

\footnotetext{
17 Imroatullayyin Makhfiyana and Mohammad Mudzakkir, "Rasionalitas Plagiarisme Di Kalangan Mahasiswa Fakultas Ilmu Sosial Unesa," Proceedings of the JISC Plagiarism: Prevention, Practice and Policies Conference 1, no. 3 (2004): 1-8.

18 "Kecamatan, Kelurahan, Dan Desa - Pemerintah Kabupaten Wonogiri," accessed November 7, 2021, https://wonogirikab.go.id/instansi/kecamatan-kelurahan-dan-desa/.
}

Al Qalam: Jurnal Ilmiah Keagamaan dan Kemasyarakatan Vol. 15, No. 2 Juli-Desember 2021 
Muhammad Yusril Marom: Strategi Pelaksanaan Kegiatan Keagamaan di Tengah Pandemi Covid-19 pada Masyarakat Kelurahan Wonokarto Kabupaten Wonogiri

dengan agama islam sebagai mayoritas. Tingginya tingkat religiusitas dipicu oleh sumber daya manusianya yang rata-rata memiliki latar belakang pendidikan agama serta keyakinan beragama yang tinggi. Hal inilah yang menjadikan masjid-masjid kemudian selalu ramai dengan kegiatan keagamaan.

Salah satu masjid yang banyak ikut berperan dalam memfasilitasi agenda keagamaan di Kelurahan Wonokarto adalah Masjid Al-Hidayah. ${ }^{19}$ Masjid terbesar di Wonokarto ini hampir tak pernah sepi akan kegiatan keagamaan, karena berada di lokasi yang strategis, dekat dengan jalan raya dan berada tepat di depan Stadion Lapangan Pringgondani membuat kegiatan keagamaan disini semakin ramai. Selain karena akses yang mudah, ada banyak sumber daya manusia berbobot yang ikut mendukung kelancaran setiap event keagamaan. Ada berbagai kegiatan keagamaan yang rutin diadakan secara berkala, mulai dari pengajian, yasinan, kegiatan TPQ, tadarus, dll.

Saat pandemi covid-19 terjadi, agenda keagamaan di Kelurahan Wonokarto tidak surut begitu saja. Masyarakat Wonokarto tetap kukuh melaksanakan kegiatan keagamaan walau dalam bentuk yang berbeda. Bahkan meski kerap terjadi ancaman patroli oleh pihak kepolisian, masyarakat Wonokarto tetap tidak gentar dan tetap memberanikan diri untuk tetap menyemarakkan syiar dakwah islam. Hal serupa terjadi di Masjid Al-Hidayah, masjid yang berada di posisi yang strategis ini tidak lepas dari pantauan pengawasan pemerintah setempat. Kegiatan yang tetap berani diadakan yaitu pengajian, bakti sosial, sholat berjama'ah termasuk Sholat Jum'at, Program Taman Pendidikan Al-Qur'an (TPQ), dan kegiatan keagamaan lainnya yang banyak mengundang kerumunan publik.

\subsection{Strategi Masyarakat dalam Pelaksanaan Kegiatan Keagamaan}

Wabah pandemi virus corona benar-benar melumpuhkan aktivitas masyarakat, termasuk dalam hal kegiatan keagamaan. Banyak kegiatan keagamaan yang kemudian harus diberhentikan dan para warga dihimbau harus tetap bisa menetap seterusnya di rumah. Perihal beribadah, pemerintah Wonogiri lebih menganjurkan warga untuk beribadah dari rumah masing-masing. Padahal kebijakan tersebut jelas berlawanan dengan tradisi warga yang lebih suka melakukan ibadah dengan berkumpul di satu tempat supaya lebih khidmah. Uniknya walaupun ada pandemi, masyarakat di Kelurahan Wonokarto tetap bersikukuh untuk mengadakan kegiatan keagamaan walau ada banyak masalah menghambat.

Dari hasil pengamatan peneliti, masyarakat Kelurahan Wonokarto beranggapan bahwa adanya pandemi covid-19 jangan sampai menghilangkan ikatan solidaritas yang ada. Mereka beranggapan apabila semua ibadah serba dirumahkan maka itu akan menghilangkan esensi yang sesungguhnya dari menunaikan ibadah, yaitu memupuk tali persaudaraan dan kekeluargaan antar umat islam. Dalam hal kaitannya dengan dengan rutinitas kegiatan keagamaan, kegiatan yang paling sering dilakukan adalah pengajian, kultum, dan tentunya Sholat Jama'ah tiap lima waktu sholat.

Penyelenggaraan kegiatan kegamaan di masa pandemi oleh masyarakat Kelurahan Wonokarto tentunya tidak semudah diadakan seperti hari normal pada umumnya. Beberapa kendala diantaranya berlawanan dengan himbauan pemerintah tentang adanya kebijakan PSBB, patroli pihak kepolisian, dan potensi penyebaran virus yang bisa terjadi sewaktu-waktu. Oleh karena itu, peneliti dalam hal ini berhasil memetakan bagaimana serangkaian strategi masyarakat Kelurahan

19 "Masjid Al Hidayah Wonokarto - Wonogiri, Jawa Tengah," idalamat.com, accessed November 7, 2021, https://idalamat.com/alamat/144923/masjid-al-hidayah-wonokarto-wonogiri-jawa-tengah.

Al Qalam: Jurnal Ilmiah Keagamaan dan Kemasyarakatan Vol. 15, No. 2 Juli-Desember 2021 
Muhammad Yusril Marom: Strategi Pelaksanaan Kegiatan Keagamaan di Tengah Pandemi Covid-19 pada Masyarakat Kelurahan Wonokarto Kabupaten Wonogiri

Wonokarto dalam melaksanakan kegiatan keagamaan di tengah wabah pandemi. Adapun strategistrategi yang dimaksud diulas secara rinci dalam penjelasan sebagai berikut:

1.) Menggenakan Alat Pelindung Diri (APD)

Saat melakukan pertemuan keagamaan, para warga Kelurahan Wonokarto dihimbau untuk selalu menaati protokol kesehatan, salah satunya dengan mengenakan alat pelindung diri atau APD. Hal Ini bertujuan supaya warga yang ikut berkumpul terhindar dari paparan virus corona. APD yang dimaksud disini adalah alat-alat kesehatan yang dapat melindungi diri dari paparan virus corona, diantaranya seperti masker, sarung tangan, penutup kepala. Penggunaan alat-alat pelindung diri tersebut seperti masker memiliki efektivitas hasil yang cukup baik dalam mencegah penularan virus yang bisa menyebar melalui pernafasan. ${ }^{20}$ Maka, dengan tetap menggunakan alat tersebut saat agenda keagamaan dapat meminimalisir penularan virus.

2.) Menyediakan Hand Sanitizer di tempat pertemuan

Hand sanitizer perlu ditaruh di ruangan tempat kegiatan keagamaan berlangsung. Masyarakat Kelurahan Wonokarto sendiri biasanya menaruh hand sanitizer di depan ruangan. Hal ini supaya setiap orang yang ingin masuk ruangan sebelum itu bisa mencuci tangannya terlebih dahulu dengan hand sanitizer. Begitupun setelah selesai kegiatan, ketika mereka akan keluar dari ruangan dianjurkan untuk tetap menggunakan hand sanitizer. Penggunaan hand sanitizer ini bagi masyarakat setempat dianggap sebagai hal yang penting, karena dengan menggunakannya dapat mengantisipasi apabila tangan memegang sesuatu yang rawan dengan virus. Oleh karena itu, di setiap tempat perkumpulan keagamaan di kelurahan Wonokarto kini disediakan hand sanitizer dan akan selalu diisi ulang apabila isinya habis secara rutin.

3.) Menerapkan pembatasan jumlah peserta forum atau dilakukan di tempat yang luas

Tidak semua warga di Kelurahan Wonokarto bisa mengikuti kegiatan keagamaan. Hal ini karena dari pihak masyarakat setempat membatasi jumlah orang yang mengikuti kegiatan keagamaan seperti pengajian, tahlilan, maupun sholat berjama'ah. Ini juga dilakukan untuk memperlihatkan kepatuhan warga terhadap kebijakan PSBB walaupun tidak sepenuhnya. Namun pembatasan ini tidak berlaku apabila tempat penyelenggaraan kegiatan berlangsung di tempat yang relatif luas seperti di Masjid Al-Hidayah, salah satu masjid di kelurahan Wonokarto. Pembatasan dari segi jumlah ini dilakukan untuk menghindari dampak penyebaran virus. Adapun alternatifnya yaitu dengan menyediakan tempat yang luas supaya para jama'ah bisa memiliki jarak yang cukup dengan banyak orang.

4.) Menerapkan physical distancing

Perkumpulan keagamaan di kelurahan Wonokarto saat pandemi menekankan pada pembatasan jarak fisik. Dalam hal ini salah satunya yang sudah diterapkan di Masjid Al-Hidayah, terdapat sekat yang sudah ditata rapi untuk membatas jarak tempat duduk antara warga satu dengan warga lainnya sebanyak satu setengah meter. Tujuannya tidak lain untuk mencegah penyebaran virus dari pola kegiatan keagamaan yang cenderung posisinya berkerumun atau berdekatan satu sama lain. ${ }^{21}$

5.) Melakukan pengecekan suhu

Pengecekan suhu diperlukan untuk mendeteksi kesehatan warga. Pengecekan suhu banyak di lakukan di depan area masjid. Sebelum masuk ke masjid, jama'ah akan dicek terlebih dahulu berapa suhunya. Apabila suhu panasnya melebih rata-rata maka warga dilarang mengikuti kegiatan

\footnotetext{
${ }^{20}$ Atmojo, dkk, "Penggunaan Masker Dalam Pencegahan Dan Penanganan Covid-19," Journal of Health Research 3, no. 2 (2020): 84-95.

${ }^{21}$ Kresna, Arief and Juni Ahyar, "Pengaruh Physical Distancing Dan Social Distancing Terhadap Keseharan Dalam Pendekatan Linguaistik," Jurnal Syntax Transformation Vol. 1, no. 4 (2020): 14-19.
}

Al Qalam: Jurnal Ilmiah Keagamaan dan Kemasyarakatan Vol. 15, No. 2 Juli-Desember 2021 
Muhammad Yusril Marom: Strategi Pelaksanaan Kegiatan Keagamaan di Tengah Pandemi Covid-19 pada Masyarakat Kelurahan Wonokarto Kabupaten Wonogiri

keagamaan. Namun strategi pengecekan suhu ini tidak banyak dilakukan dan hanya dilakukan di beberapa forum saja, lantaran keterbatasan alat yang dimiliki oleh sebagian masjid.

6.) Durasi waktu kegiatan dipersingkat

Kegiatan keagamaan yang biasanya berlangsung lebih santai dan lama namun ketika pandemi menjadi lebih cepat selesai. Warga di Kelurahan Wonokarto dalam mengadakan kegiatan keagamaan tidak boleh lebih dari kisaran satu jam untuk menghindari kerumunan yang berkepanjangan yang mana dapat menyebabkan penyebaran virus. Setelah agenda keagamaan selesai diadakan, para warga dianjurkan untuk langsung pulang tanpa membuat kerumunan walaupun itu sebentar.

7.) Tidak ada undangan secara resmi

Sebelum pandemi, penyelenggaraan kegiatan keagamaan selalu dibarengi dengan penyebaran undangan kepada khalayak umum dalam bentuk surat undangan, poster, pendirian banner besar, dan penyebaran informasi melalui internet maupun jejaring media sosial. Hal tersebut berbeda saat pandemi karena dari pihak masjid tidak lagi menyebarkan undangan. Adapun jama'ah yang datang biasanya datang dengan sendirinya atau datang dari ajakan teman terdekat, tanpa ada info resmi pengadaan kegiatan. Kegiatan keagamaan lebih dikemas secara tertutup alias sembunyi-sembunyi untuk menghindari kisruh keramaian masyarakat yang dapat berpotensi mengundang razia.

\subsection{Rasionalitas Masyarakat Kelurahan Wonokarto dalam Kegiatan Keagamaan}

Masyarakat Kelurahan Wonokarto memiliki strategi untuk tetap mengupayakan penyelenggaraan kegiatan keagamaan di tengah masa pandemi. Apa yang sudah dilakukan masyarakat dalam kacamata pemikiran Max Weber merupakan bentuk dari tindakan sosial. Tindakan sosial merujuk dari pemikiran Weber menunjukkan bahwa setiap tindakan yang dilakukan individu memiliki arti atau makna subjektif yang mana diklaim benar oleh pelaku dan ini yang mendorong individu untuk melakukan suatu perbuatan. Menurut Weber, tindakan sosial yang dilakukan manusia diarahkan kepada individu lain sesama makhluk hidup, seperti misalnya tindakan seseorang terhadap orang lain. ${ }^{22}$ Dari apa yang mendorong individu berbuat, timbul sebuah tindakan rasional yang dimiliki individu dengan berbagai motif di belakangnya. Ada empat macam tindakan sosial menurut Max Weber, diantaranya tindakan rasional berorientasi nilai, rasionalitas instrumental, tindakan tradisional, dan tindakan afektif. ${ }^{23}$

Pertama adalah tindakan rasional berorientasi pada nilai. Tindakan ini berhubungan dengan komitmen yang dilakukan dengan penuh kesadaran dan tidak terlepas dari nilai-nilai yang dianut pada setiap prinsip individu. Tindakan ini dapat ditunjukkan melalui komitmen masyarakat Wonokarto untuk menjaga nilai-nilai religius yang sudah tertanam pada struktur masyarakat. Jika dikaitkan dalam penelitian ini, konsep rasionalitas nilai dapat ditunjukkan melalui perkumpulan pengajian rutin yang dilakukan masyarakat setempat. Aktivitas ini dianggap memiliki nilai luhur untuk menanamkan nilai-nilai moralitas, kebaikan dan kepedulian antar sesama warga.

Yang kedua, tindakan rasionalitas instrumental, yaitu tindakan yang berhubungan dengan tindakan sosial manusia yang didasarkan atas pertimbangan dan pilihan sadar yang berhubungan dengan tujuan tindakan itu dan ketersediaan alat untuk mencapainya. Jika dilihat dalam konteks penelitian ini, upaya masyarakat yang secara sadar dilakukan untuk mencapai tujuan dapat

${ }^{22}$ George Ritzer, "Teori Sosiologi Dari Sosiologi Klasik Sampai Perkembangan Akhir Post Modern" (Yogyakarta: Pustaka Pelajar, n.d.), 232-33.

${ }^{23}$ Martinus Legowo, Nurfianah, "Strategi Adaptasi Masyarakat Petani Pemilik Lahan Di Desa Bojoasri Kecamatan Kalitengah Lamongan Dalam Menghadapi Banjir,” Journal Paradigma 05, no. 03 (2017): 3.

Al Qalam: Jurnal Ilmiah Keagamaan dan Kemasyarakatan Vol. 15, No. 2 Juli-Desember 2021 
Muhammad Yusril Marom: Strategi Pelaksanaan Kegiatan Keagamaan di Tengah Pandemi Covid-19 pada Masyarakat Kelurahan Wonokarto Kabupaten Wonogiri

ditunjukkan yaitu dengan menerapkan protokol kesehatan ketika mengadakan kegiatan keagamaan, seperti dengan selalu menggunakan masker, berjaga jarak, dan membatasi jumlah peserta saat kegiatan keagamaan dilakukan. Hal tersebut bertujuan supaya warga setempat bisa mengurangi resiko dampak penyebaran virus covid-19 dan agar agenda keagamaan dapat berlangsung dengan aman.

Ketiga adalah tindakan tradisional. Tindakan tradisional adalah tindakan yang cenderung dilakukan secara berulang dan telah menjadi kebiasaan yang mendarahdaging pada masyarakat, tidak menjadi persoalan, dan keberadaannya dianggap sebagai hal yang lazim. Tindakan ini biasanya kerap dilakukan secara turun-temurun antar generasi ke generasi lainnya. Jika dihubungkan dengan kasus pada penelitian ini, aktivitas keagamaan seperti yasinan dan tahlilan sudah menjadi budaya masyarakat setempat sejak dulu kala. Kegiatan keagamaan ini dilakukan secara turun-temurun dari dulu sampai sekarang untuk dilestarikan nilai-nilai kebaikannya agar tidak cepat pudar.

Yang keempat, tindakan afektif, yaitu tindakan yang berkaitan dengan emosi yang dimiliki oleh seseorang. Dalam hubungannya dengan kasus pada penelitian ini, tindakan afeksi ditunjukkan melalui hubungan kekerabatan antar warga yang mana dengan adanya kegiatan keagamaan ini dapat membuat hubungan emosional semakin erat dan memupuk tali persaudaraan. Bahkan walaupun di tengah masa pandemi ini, persaudaraan warga masih tetap terjalin dengan adanya kegiatan keagamaan ini yang dapat memupuk rasa cinta dan solidaritas sosial antar sesama.

\section{KESIMPULAN}

Di tengah keterbatasan saat pandemi covid-19, warga Kelurahan Wonokarto tetap giat melakukan aktivitas keagamaan. Dalam menunaikan aktivitas keagamaan, masyarakat setempat memiliki strategi yang digunakan untuk memperlancar jalannya setiap tindakan meskipun terdapat banyak hambatan. Berdasarkan hasil temuan peneliti apabila dihubungkan dengan teori rasionalitas Max Weber, maka bisa diketahui bahwa strategi tindakan yang dilakukan masyarakat Kelurahan Wonokarto dalam melaksanakan kegiatan keagamaan dapat diklasifikasikan menjadi empat jenis, yaitu tindakan rasional berorientasi nilai, rasionalitas instrumental, tindakan tradisional, dan tindakan afektif.

Tindakan rasional berorientasi pada nilai dapat ditunjukkan melalui perkumpulan pengajian rutin yang dilakukan masyarakat setempat. Aktivitas ini dianggap memiliki nilai luhur untuk menanamkan nilai-nilai moralitas, kebaikan dan kepedulian antar sesama warga. Tindakan rasionalitas instrumental dapat ditunjukkan melalui upaya masyarakat yang secara sadar dilakukan untuk mencapai tujuan. Dalam penelitian ini ditunjukkan melalui kesadaran warga dalam menerapkan protokol kesehatan ketika mengadakan kegiatan keagamaan untuk mengurangi resiko dampak penyebaran virus corona, seperti dengan selalu menggunakan masker, berjaga jarak, dan membatasi jumlah peserta saat kegiatan keagamaan dilakukan. Tindakan tradisional dapat dilihat bahwa pengadaan kegiatan keagamaan sudah menjadi budaya masyarakat setempat sejak dulu kala. Kegiatan keagamaan ini dilakukan secara turun-temurun dari dulu sampai sekarang untuk dilestarikan nilai-nilai kebaikannya agar tidak cepat pudar. Terakhir, tindakan afektif ditunjukkan melalui perasaan emosional pada hubungan kekerabatan antar warga. Adanya kegiatan keagamaan walau di tengah masa pandemi membuat solidaritas masyarakat Kelurahan Wonokarto justru menjadi semakin erat dan mampu memperkuat tali persaudaraan.

Al Qalam: Jurnal Ilmiah Keagamaan dan Kemasyarakatan Vol. 15, No. 2 Juli-Desember 2021 
Muhammad Yusril Marom: Strategi Pelaksanaan Kegiatan Keagamaan di Tengah Pandemi Covid-19 pada Masyarakat Kelurahan Wonokarto Kabupaten Wonogiri

\section{DAFTAR PUSTAKA}

Aeni, Siti Nur. "Mengulas Enam Agama Di Indonesia Dari Sejarah Sampai Tempat Ibadah Nasional Katadata.Co.Id.” $\quad 2021$. https://katadata.co.id/sitinuraeni/berita/615bd585217fe/mengulas-enam-agama-di-indonesiadari-sejarah-sampai-tempat-ibadah.

Ahyar, Juni, dan Arief Kresna. "Pengaruh Physical Distancing Dan Social Distancing Terhadap Keseharan Dalam Pendekatan Linguaistik." Jurnal Syntax Transformation Vol. 1, no. 4 (2020): 14-19.

Atmojo, Joko Tri, Dkk. "Penggunaan Masker Dalam Pencegahan Dan Penanganan Covid-19." Journal of Health Research 3, no. 2 (2020): 84-95.

Damaledo, Yandri Daniel. "2 Maret 2020 Kasus Corona Pertama Di Indonesia Diumumkan Tahun Lalu." Tirto.id, 2021. https://tirto.id/2-maret-2020-kasus-corona-pertama-di-indonesiadiumumkan-tahun-lalu-gaKw.

Darmawan, Dadang, Deni Miharja, Roro Sri Rejeki Waluyajati, and Erni Isnaeniah. "Sikap Keberagamaan Masyarakat Menghadapi Wabah COVID-19." Religious: Jurnal Studi AgamaAgama Dan Lintas Budaya 4, no. 2 (2020): 115-24. https://doi.org/10.15575/rjsalb.v4i2.8596.

H. Usman, Mukran, Aswar Aswar, and Andi Wahyu Irawan. "Syariat Islam Dan Kemaslahatan Manusia Di Era New Normal Pada Kegiataan Keagamaan Dan Pendidikan." Fenomena 12, no. 1 (2020): 89-106. https://doi.org/10.21093/fj.v12i1.2456.

Ika. "Mahfud MD Tegaskan Indonesia Bukan Negara Agama | Universitas Gadjah Mada." ugm.ac.id, 2018. https://www.ugm.ac.id/id/berita/16888-mahfud-md-tegaskan-indonesiabukan-negara-agama.

Indonesia, Presiden Republik. Undang Undang Nomor 6 tahun 2018 tentang Kekarantinaan Wilayah, Undang-Undang RI § (2018). https://jdih.bsn.go.id/produk/detail/?id=730\&jns=2.

Istriyani, Ratna, and Muhammad Fathur Rahman. "Representasi Masyarakat Aktif Di Masa Pandemi Covid-19 (Studi Ekonomi Dan Sosial Keberagamaan Di Bausasran Danurejan Yogyakarta)." Jurnal Penelitian 14, no. 2 (2020): 185-216. https://doi.org/10.21043/jp.v14i2.8108.

Moleong Lexy J. “Metodologi Penelitian KualitatiI," 11. Bandung: PT. Remaja Rosadakarya, 2011.

"Kecamatan, Kelurahan, dan Desa - Pemerintah Kabupaten Wonogiri." Accessed November 7, 2021. https://wonogirikab.go.id/instansi/kecamatan-kelurahan-dan-desa/.

Makhfiyana, Imroatullayyin, and Mohammad Mudzakkir. "Rasionalitas Plagiarisme Di Kalangan Mahasiswa Fakultas Ilmu Sosial Unesa." Proceedings of the JISC Plagiarism: Prevention, Practice and Policies Conference 1, no. 3 (2004): 1-8.

idalamat.com. "Masjid Al Hidayah Wonokarto - Wonogiri, Jawa Tengah." Accessed November 7, 2021. https://idalamat.com/alamat/144923/masjid-al-hidayah-wonokarto-wonogiri-jawatengah.

Mustofa, Ali. "Di Karangasem, Upacara Melasti Dibatasi Maksimal 20 Orang." radarbali.jawapos.com, 2021. https://radarbali.jawapos.com/beritadaerah/dwipa/08/03/2021/di-karangasem-upacara-melasti-dibatasi-maksimal-20-orang.

Nurfianah, Martinus Legowo. "Strategi Adaptasi Masyarakat Petani Pemilik Lahan Di Desa Bojoasri Kecamatan Kalitengah Lamongan Dalam Menghadapi Banjir." Journal Paradigma 05, no. 03 (2017): 3.

Prabowo, Ronald Seger. "Resmi! Perayaan Waisak 2021 Di Borobudur Ditiadakan - Suara Jateng." suarajawatengah.id, 2021. https://jateng.suara.com/read/2021/05/24/193149/resmi-perayaanwaisak-2021-di-borobudur-ditiadakan.

Rahmawati, Yasinta. "Dari China, Begini Awal Penyebaran Virus Corona Ke Seluruh Dunia." Suara.com, 2020. https://www.suara.com/health/2020/04/04/183648/dari-china-begini-carapenyebaran-virus-corona-ke-seluruh-dunia?page=all.

Al Qalam: Jurnal Ilmiah Keagamaan dan Kemasyarakatan Vol. 15, No. 2 Juli-Desember 2021 
Muhammad Yusril Marom: Strategi Pelaksanaan Kegiatan Keagamaan di Tengah Pandemi Covid-19 pada Masyarakat Kelurahan Wonokarto Kabupaten Wonogiri

Ritzer, George. "Teori Sosiologi Dari Sosiologi Klasik Sampai Perkembangan Akhir Post Modern," 232-33. Yogyakarta: Pustaka Pelajar, n.d.

Rizal, Fadli. "Coronavirus." Halodoc.com, 2021. https://www.halodoc.com/kesehatan/coronavirus. Sainuddin, Ibnu Hajar. "Transformasi Dakwah Di Masa Pandemi Covid-19," 2020, 19-21. https://doi.org/10.31219/osf.io/nakhy.

Syarifudin, Albitar Septian. "Impelementasi Pembelajaran Daring Untuk Meningkatkan Mutu Pendidikan Sebagai Dampak Diterapkannya Social Distancing." Jurnal Pendidikan Bahasa Dan Sastra Indonesia Metalingua 5, no. 1 (2020): 31-34. https://doi.org/10.21107/metalingua.v5i1.7072.

Tobroni, Faiq. "Pembatasan Kegiatan Keagamaan Dalam Penanganan Covid-19." Jurnal Komunikasi Hukum (JKH) Universitas Pendidikan Ganesha Vol. 6, no. 2 (2020): 369-95.

Utama, Abraham. "Paskah 2020 Di Tengah Epidemi Virus Corona: 'Sejak Zaman Nenek Moyang, Baru Kali Ini Kami Dilarang Ke Gereja' - BBC News Indonesia." BBC News Indonesia, 2020. https://www.bbc.com/indonesia/indonesia-52229367.

Al Qalam: Jurnal Ilmiah Keagamaan dan Kemasyarakatan Vol. 15, No. 2 Juli-Desember 2021 